\title{
Effects of habitat on the settlement and post- settlement success of the ocean surgeonfish Acanthurus bahianus
}

\author{
Andrea Risk* \\ Department of Biological Sciences, University of Windsor, Windsor, Ontario, Canada N9B 3P4
}

\begin{abstract}
Local population dynamics of fishes on coral reefs are dependent on processes affecting the settlement of pelagic larvae and the subsequent persistence of these new settlers. The ability of larvae to choose favourable places to settle in terms of persistence may make the dynamics of certain populations predictable at the reef scale, and cause patterns of recruitment to differ from those of larval supply. I collected data on settlement, recruitment and persistence of the ocean surgeonfish Acanthurus bahianus in different physiographic zones of the Tague Bay reef, on the island of St. Croix, U.S. Virgin Islands. There was significantly higher settlement and recruitment to the back-reef zone than to the fore-reef zone or seagrass zones at the bases of the back-reef and fore-reef, suggesting that larvae select settlement sites and do not necessarily settle to the first reef zone encountered. On the back-reef, settlers used pavement more than any other type of substratum, and the post-settlement persistence of settlers and recruits was highest on pavement when compared to these other substrata. These results suggest that patterns of ocean surgeonfish settlement are affected by reef-based processes, and that selection for certain zones and substrata occurs. Subsequent modification of these initial settlement patterns by increased persistence in preferred habitats adds predictability to patterns of recruitment, resulting in larval supply alone being an insufficient explanation of the distribution and abundance of ocean surgeonfish populations at this scale.
\end{abstract}

KEY WORDS: Coral reef fish - Caribbean - Otoliths . Habitat selection - Recruitment - Growth Persistence

\section{INTRODUCTION}

Most marine organisms, including the majority of coral reef fishes, have a life cycle that includes a pelagic larval stage and a demersal, relatively siteattached, adult stage (Ehrlich 1975, Butman 1987, Roughgarden et al. 1988). For these species, the local persistence of adult populations is highly dependent on the input of new individuals that settle to benthic habitats from the plankton (Sale 1980, Doherty et al. 1985, Milicich et al. 1992). However, recruitment (the addition of new individuals) is highly variable in both space and time (Sale et al. 1984a, Caffey 1985, Doherty 1987, Doherty \& Williams 1988, Raimondi 1990, Fowler

\footnotetext{
•E-mail: sale@server.uwindsor.ca
}

et al. 1992). Not only are the distribution and abundance of adult populations influenced by this variation (Doherty 1981, Victor 1983, 1986b, Doherty \& Fowler 1994b), but often local age-structures are as well (Doherty \& Fowler 1994a, b). Assuming that recruitment patterns reflect pelagic events and not early postsettlement events, there is considerable argument as to the importance of these pelagic processes relative to other processes affecting population dynamics of coral reef fishes (Jones 1991).

While planktonic, a larval fish must obtain food and avoid predation, as well as make its way to an area suitable for settlement. Interactions with other pelagic species, in addition to movement of the surrounding water masses, are important in determining the success of individuals and may have strong effects on the distribution and abundance of competent larvae (Leis 
1991). The length of time spent in the plankton varies both within and among taxa (Victor 1986a, Fowler 1989, Thresher et al. 1989, Wellington \& Victor 1989), and the ability to delay metamorphosis may be an adaptation for maximizing the return of larvae to suitable coral reef environments (Victor 1986c).

Although pelagic processes are important in determining the dynamics of populations of coral reef fish, reefal processes may also be important. While settling, larvae often show preferences for places that contain conspecifics (Sweatman 1985, 1988, Jones 1987, Booth 1992) and for certain habitats (Bell \& Galzin 1984, Sale et al. 1984b, Eckert 1985, Victor 1986b). Later in life, habitat may influence post-settlement interactions with reef residents (Itzkowitz 1977, Choat \& Bellwood 1985, Ebersole 1985, Jones 1990). Because reef substrata provide food (Jones 1986, Schmitt \& Holbrook 1986, Forrester 1990, Levin 1994) and shelter from predation (Shulman 1984, Hixon \& Beets 1989, 1993), habitat can also influence post-settlement persistence (Aldenhoven 1986, Jones 1986, Eckert 1987, Booth \& Beretta 1994).

Investigations of the relative importance of pelagic and demersal processes have, for the most part, been

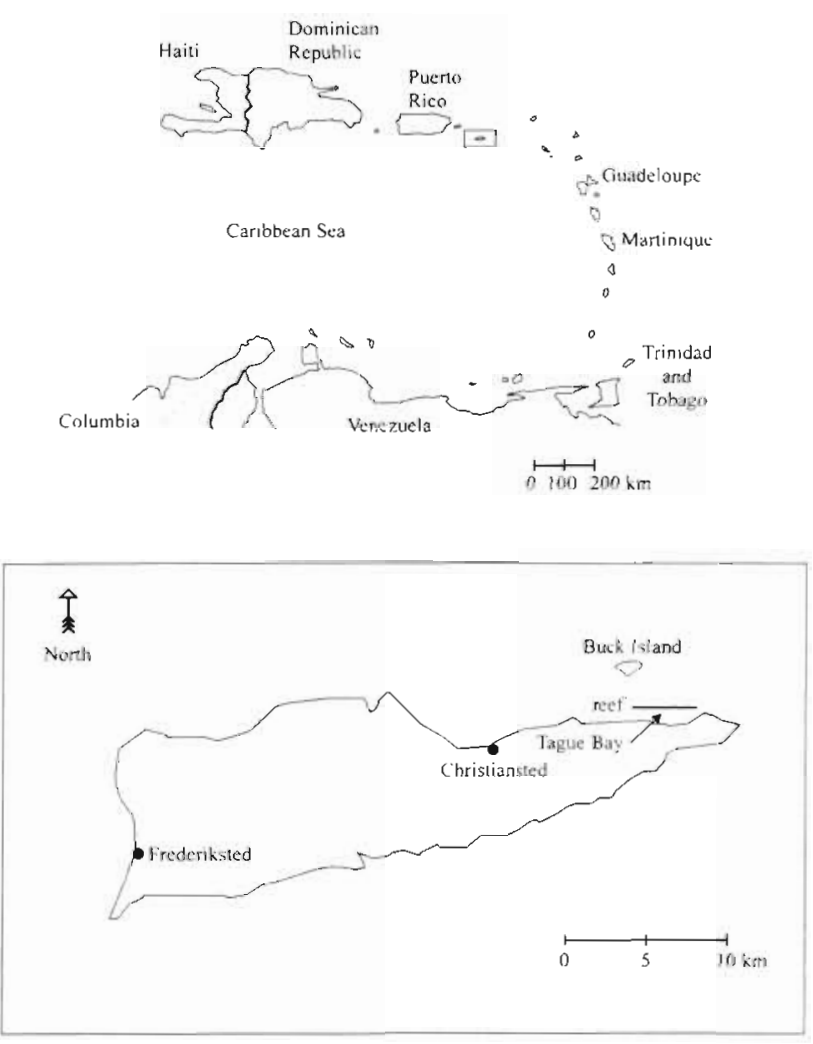

Fig. 1. Location of St. Croix within the Caribbean Sea. Enlargement shows Tague Bay and Tague Bay reef, where the study was conducted limited to pomacentrid and labrid species (Doherty \& Williams 1988), and have been conducted within a single habitat or on small homogeneous arrays (Mapstone \& Fowler 1988). It is thus unclear how generally applicable the results from these studies are. Specifically, it is doubtful that the results from such studies can be applied to non-pomacentrid or non-labrid species of fish living in highly heterogeneous habitats.

In order to obtain a broader understanding of the population dynamics of coral reef fish, it is therefore essential to study different species and to examine the effects of both pre-settlement and post-settlement events within the mosiac of habitats in which individuals occur. In this paper, I examine patterns of settlement and recruitment of the ocean surgeonfish Acanthurus bahianus on the Tague Bay reef, St. Croix, U.S. Virgin Islands. Three questions are addressed: (1) What is the pattern of settlement and recruitment of ocean surgeonfish in different physiographic zones of the reef? (2) What is the distribution of settlers among particular types of substrata within one of these zones? (3) Are there differences in the persistence of settlers and recruits among particular types of substrata within this zone?

\section{METHODS}

Study site. Tague Bay is on the northeast side of St. Croix (Fig. 1), and is enclosed by a bank-barrier reef. The reef can be divided into 3 main physiographic zones: the reef flat, the back-reef and the fore-reef, The reef flat is the shallowest part of the reef and is often partially exposed at low tide. The back-reef is inside the reef flat, facing the shore of St. Croix. At the base of the back-reef (approx. $4 \mathrm{~m}$ depth), there are scattered seagrass beds (Thalassia testudinum) and large expanses of sand. The fore-reef is outside the reef flat, and faces the open ocean. At the base of the fore-reef (approx. $15 \mathrm{~m}$ depth) there are also scattered seagrass beds (Syringodium filiforme) and sandcovered areas. The reef surface is comprised mainly of dead Acropora palmata rubble and pavement (smooth, algae-covered areas), with an occasional large head of Porites porites or Montastrea annularis.

Study species. The ocean surgeonfish Acanthurus bahianus (Castelnau) (Pisces: Acanthuridae) is a common herbivore on coral reefs in the Caribbean (Randall 1965, Ogden 1976). Accompanied by A. chirurgus and $A$. coeruleus, adults graze the reef in large heterospecific schools (pers. obs.). Ocean surgeonfish spawn both in pairs and in large groups, producing fertilized pelagic eggs (Colin \& Clavijo 1988). While the larval duration of ocean surgeonfish settling to Barbados ranges from 44 to $69 \mathrm{~d}$ (Sponaugle \& Cowen 1996), it is 
not known whether the larval duration of ocean surgeonfish settling to St. Croix is similar

Settlement of competent larvae to the reef occurs during the night and follows a lunar cycle, being maximum around the new moon (Robertson 1988, 1992, Sponaugle \& Cowen 1996). Settlement intensity varies both spatially and temporally (Robertson 1992), and there is evidence from confamilials that settlers actively choose where to settle based on the amount and kind of cover available, depth, and presence of conspecifics (Sale 1968, 1969a, b). Recently-settled individuals are transparent except for a silvery gut and operculum (pers. obs.), thus allowing settlers to be easily distinguished from recruits. On reefs in Panama, new settlers range in standard length between 23 and $33 \mathrm{~mm}$, with the average being $26.9 \mathrm{~mm}$ (Robertson 1992). Settlers seek shelter immediately and begin to metamorphose, which involves lengthening the gut and acquiring scales and adult colouration (Randall 1961)

Among-zone patterns of settlement and recruitment. To determine whether ocean surgeonfish settlement and/or recruitment varies within the Tague Bay reef, I collected settlers and recruits in each of 4 reef zones. I established 2 permanent $25 \mathrm{~m}^{2}$ quadrats in each of 8 sites: areas of pavement on the eastern forereef, areas of pavement on the western fore-reef, areas of pavement on the eastern back-reef, areas of pavement on the western back-reef, areas of seagrass at the base of the eastern fore-reef, areas of seagrass at the base of the western fore-reef, areas of seagrass at the base of the eastern back-reef, and areas of seagrass at the base of the western back-reef. There were therefore 2 sites (with 2 quadrats within each site) per zone, zones being fore-reef pavement, back-reef pavement, fore-reef seagrass and back-reef seagrass. The 2 quadrats within each of the 8 sites were at least $10 \mathrm{~m}$ apart, and the 2 sites within each of the 4 zones were at least $500 \mathrm{~m}$ apart.

All quadrats were delineated with large roofing nails and string. I attempted to match the fore-reef and back-reef pavement areas and the fore-reef and backreef seagrass areas as closely as possible in terms of depth and substratum.

Every 10 to $14 \mathrm{~d}$ from mid-June to mid-August 1995 . while on SCUBA, I collected all settlers (translucent, with silvery operculi) and recruits (total length $<50 \mathrm{~mm}$, but not recent settlers) from each of the 16 quadrats using quinaldine (2-methylquinoline), a fish anesthetic, and aquarium hand-nets. Each collection was completed within a single day. Settlers were easily distinguished from recruits by colouration. A total of 6 collections were completed.

Both the mean number of settlers and the mean number of recruits collected from mid-June to mid-
August were compared among the 4 zones with 2-way ANOVAs (side of reef and substratum type as fixed factors). Because there were no differences between the sites in each zone, the effect of site was removed from the analysis, thus providing 4 quadrats per zone. All collections were pooled for each quadrat. Data were $\log _{e}(x+0.5)$ transformed prior to analysis to achieve homoscedasticity. When the overall ANOVAs were significant, I used post-hoc pair-wise comparisons to test for differences among zones (Bonferronicorrected, overall $\alpha=0.05$ ).

Within-zone patterns of settlement and persistence. Because settlers were most abundant on the back-reef (see 'Results'), I examined smaller-scale factors within this zone. To determine whether ocean surgeonfish settlers were non-randomly distributed among substratum types on the back-reef, I compared substratum availability and settler habitat usage. I censused the substrata with 47 haphazardly-placed line transects, $20 \mathrm{~m}$ long, parallel to the reef crest. I recorded what substratum type was directly beneath the transect tape every $20 \mathrm{~cm}$ (100 observations per transect). Substratum usage was measured by monitoring 139 haphazardly-selected settlers for 10 min each, and recording what substratum type was directly beneath each individual every $15 \mathrm{~s}$ (40 observations per recruit). While substrata were censused on SCUBA, substratum usage was measured on snorkel, as the sound of underwater breathing and the release of bubbles often disturb young ocean surgeonfish (pers. obs.).

Both substratum availability and substratum usage were measured during the 2 wk around the June 1995 new moon, when ocean surgeonfish settlers were abundant. A G-test compared substratum availability and substratum usage by settlers. Substratum categories with low frequencies $(<5)$ were combined.

To elucidate the effect of substratum on persistence. I monitored the presence of 40 ocean surgeonfish setthers on the back-reef whose home areas were comprised of different substrata. These observations were conducted around the July 1995 new moon. Individuals were captured with quinaldine and aquarium hand nets. Each fish was uniquely fin-clipped for identification, measured, and then immediately released to the place where it had first been seen. Small clips were made in different regions of the dorsal fin, the anal fin, or both. Individuals were held for less than $30 \mathrm{~s}$. The sites where each of the settlers had been captured were marked with numbered pieces of flagging tape, allowing all individuals to be cross-referenced by finclip and flagging tape number. As I wanted to exclude any settler that had died or been seriously injured by the clipping, I began the experiment the day after clipping and included only those individuals which could then be located. Fin-clipped settlers were monitored 

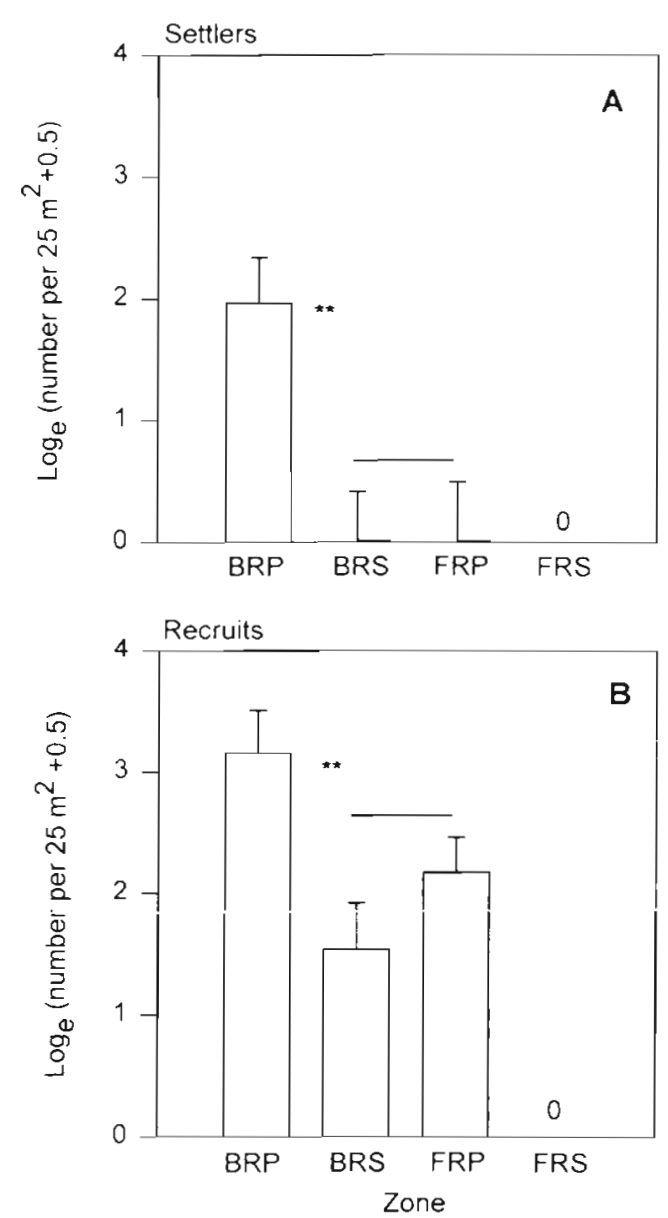

Fig. 2. Acanthurus bahianus. Mean number of ocean surgeonfish (A) settlers and (B) recruits collected from four $25 \mathrm{~m}^{2}$ quadrats in each of 4 reef zones (BRP: back-reef pavement, BRS: back-reef seagrass, FRP: fore-reef pavement, FRS: forereef seagrass). Horizontal bars: zones that cannot be distinguished statistically; ${ }^{\prime}$ zones that differ statistically at $p<$ 0.01 . Error bars are $+1 \mathrm{SE}$

every other day, until the study was terminated at the end of 2 wk because the clipped fins were growing and becoming difficult to distinguish. Each individual was given a persistence score, based on the number of days that I had been able to relocate it. A settler was deemed gone only if I had been unable to find it on 2 consecutive searches. Throughout this study I thoroughly searched the immediate area as well as much of the surrounding area, and never found a fin-clipped settler more than a few meters away from its flagged home area. This suggests that persistence is a measure of survival and not of lack of emigration.

Persistence was compared among substrata with an ANCOVA, using total length as the covariate. The existence of parallel relationships among substrata between persistence and total length was tested by comparing the slopes of the separate regression lines.
Differences among substrata in persistence at a given total length were compared by testing the intercepts of the regression lines.

\section{RESULTS}

\section{Among-zone patterns of settlement and recruitment}

No settlers or recruits were ever seen in the fore-reef seagrass, thereby reducing the number of zones from which ocean surgeonfish were collected from 4 to 3 . The planned analyses (2-way ANOVAs) were thus modified to 1-way ANOVAs among zones.

The mean number of settlers collected per quadrat over the entire collection period (mid-June to midAugust) differed significantly among the 3 reef zones (ANOVA, $F=5.60, \mathrm{df}=2,11, \mathrm{p}<0.05$ ). On average, the back-reef pavement zone received more settlers per $25 \mathrm{~m}^{2}$ than did either the back-reef seagrass or fore-reef pavement zones (Fig. 2A). The mean number of recruits collected per quadrat over the entire period shows the same pattern, with the mean number of recruits being greatest in the back-reef pavement quadrats (ANOVA, $F=8.01, \mathrm{df}=2,11, \mathrm{p}=0.01)($ Fig. $2 \mathrm{~B})$.

\section{Within-zone patterns of settlement and persistence}

On a smaller scale, within the back-reef, the substrata most frequently used by settlers were significantly different from those which were most abundant ( $G$-test, $G=66.97, \mathrm{p}<0.001$ ). Settlers appeared to use pavement in a greater frequency than its relative availability $(22.22 \%$ of time vs $6.98 \%$ availability), and avoid dead Acropora palmata (3.70\% vs $16.28 \%$ ) and sand (5.19\% vs $20.93 \%$ ) (Fig. 3). Because of low cell frequencies, it was not possible to determine differences in usage among the various types of algae.

The persistence of ocean surgeonfish settlers was compared among the 3 substratum categories for which there were enough data (pavement, dead Acropora palmata, and sand). Because the study was terminated after $14 \mathrm{~d}$, thus artificially bounding the persistence scores, 2 analyses were conducted: one including all of the data points and one excluding from the pavement data a possible influential outlier having a persistence score of 14 . In the first analysis, substrata had a significant effect on persistence, as did the covariate total length (Table 1A). Regression equations of the persistence of settlers on different substrata vs the total lengths of the settlers were parallel, although the intercepts differed (Fig. 4). When I tested among the intercepts, I found that, while there was no difference in persistence between those settlers that lived in 


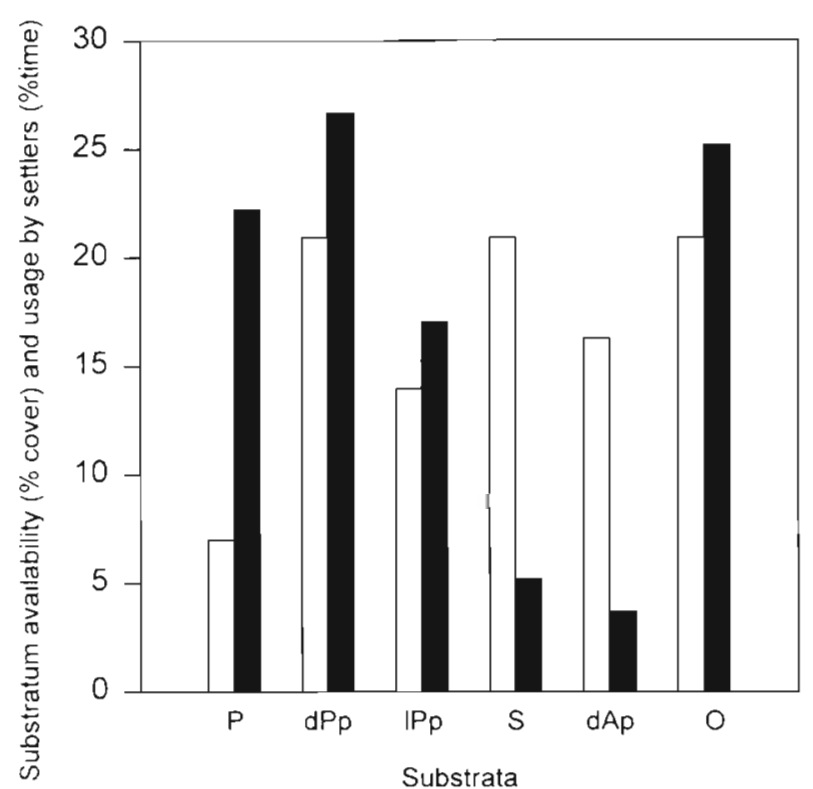

Fig. 3. Acanthurus bahianus. Comparison of substratum availability (open bars) and substratum usage (filled bars). There are 6 substratum categories (P: pavement; $\mathrm{dPp}$ : dead Porites porites; IPp: live P. porites; $\mathrm{S}$ : sand; $\mathrm{dAp}$ : dead Acropora palmata; $O$ : other). Substratum categories with low cell frequencies $(<5)$ were combined to form the category 'other'

Table 1 Acanthurus bahianus. ANCOVA of effect of backreef substratum type on the persistence of ocean surgeonfish settlers (A) with and (B) without possible outlier. Total length is the covariate

\begin{tabular}{|lrrc|}
\hline Source & df & $F$ & $p$ \\
\hline (A) With outlier & & & \\
Total length of settler & 1 & 63.240 & $<0.001$ \\
Substratum type & 2 & 13.089 & $<0.001$ \\
$\quad$ Total length of settler $x$ & 2 & 0.427 & 0.658 \\
$\quad$ substratum type & & & \\
Error & 23 & & \\
(B) Without outlier & & & \\
Total length of settler & 1 & 271.09 & $<0.001$ \\
Substratum type & 2 & 7.842 & $<0.01$ \\
Total length of settler $\times$ & 2 & 11.241 & $<0.001$ \\
$\quad$ substratum type & & & \\
Error & 22 & & \\
\hline
\end{tabular}

sandy areas and those that lived in areas dominated by dead A. palmata (2-tailed Student's $t$-test, $t=1.01, \mathrm{df}=$ 17. $p>0.1$ ), those that lived on pavement had significantly higher persistence (2-tailed Student's $t$-test, $t=$ 2.54, df $=26, p<0.05$ ).

In the second analysis, regression equations of persistence on different substrata vs total length were not parallel, indicating that there was a significant interaction between these 2 variables (Table $1 B$ ). While again

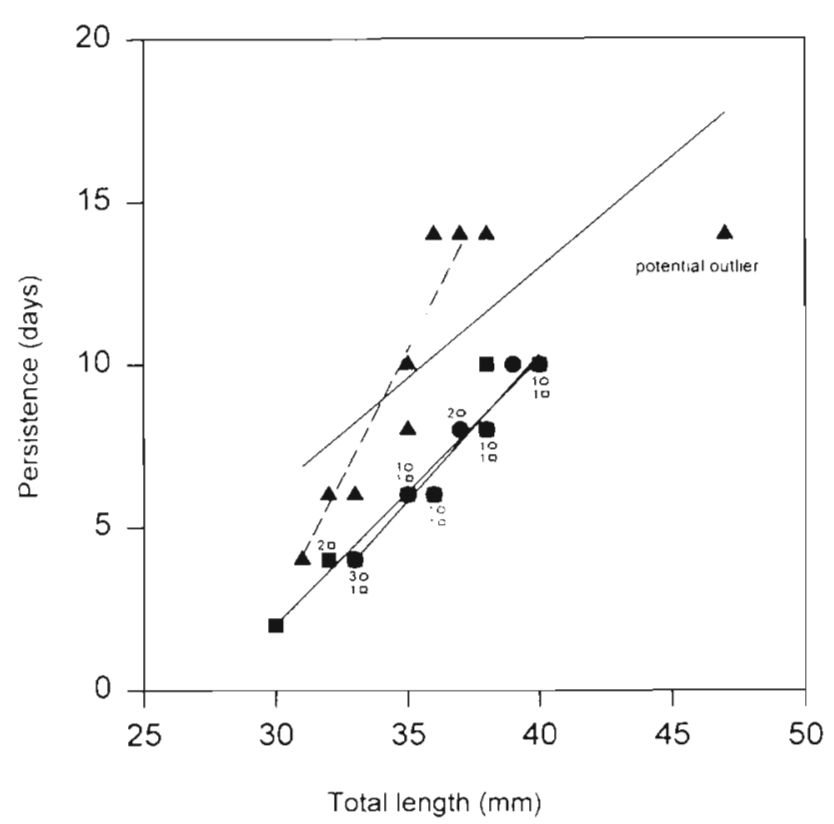

Fig. 4. Acanthurus bahianus. Relationship between persistence and total length of ocean surgeonfish settlers. With all data points included, back-reef substratum type (- dead Acropora palmata, $\mathrm{n}=10 ; \mathbf{\square}$, sand, $\mathrm{n}=9 ; \boldsymbol{\Delta}$, pavement, $\mathrm{n}=10$ ) had a significant effect on persistence, resulting in individuals on pavement having higher persistence than those on the other 2 substrata over all total lengths measured (solid lines). With the potential outlier excluded from the pavement data (dashed line) there was a significant interaction between persistence and total length, resulting in individuals on pavement having higher persistence than those on the other 2 substrata only at larger total lengths. Small numbers and symbols on the figure indicate the number of data points for each substratum type where data points overlie

there was no difference in persistence between those settlers that lived in sandy areas and those that lived in areas predominated by dead Acropora palmata (2tailed Student's $t$-test, $t=1.01, \mathrm{df}=17, \mathrm{p}>0.1$ ), those that lived on pavement had higher persistence as total length increased (Fig. 4). Based on these data alone, it is impossible to determine whether persistence of ocean surgeonfish settlers was greater on pavement relative to sand and dead $A$. palmata at all total lengths (first analysis), or whether this effect was seen only in larger individuals (second analysis).

\section{DISCUSSION}

\section{Among-zone patterns of settlement, recruitment and growth}

Variation in settlement and recruitment of several species of coral reef fishes has been noted both on the Great Barrier Reef, Australia, and in the Caribbean 
(Doherty 1981, Doherty \& Williams 1988). The extent of this variation is often dependent on the spatial and temporal scale of the study (Victor 1986b, Raimondi 1990, Tolimieri 1995). At the scale of physiographic zones on a reef, relative recruitment densities to different zones are often predictable because of the effects of habitat choice (Williams 1991). Fowler (1990), for example, documented the distribution of 23 species of butterfly fishes on One Tree Reef, Great Barrier Reef, and found that there were significant differences in adult abundance among locations. Adults of Chaetodon rainfordi, the most widely distributed species, were most abundant on a leeward reef slope and a small lagoon area filled with small coral heads. In a later study, Fowler et al. (1992) attributed this distribution to differential settlement.

Ocean surgeonfish showed variation in settlement and recruitment densities in different zones of the Tague Bay reef, with maximal densities of both settlers and recruits on the shallow back-reef. Similarly, Mahon \& Mahon (1994) reported that ocean surgeonfish juveniles in the Bahamas are predominantly found in shallow tidepools. Additional studies have shown that other species of surgeonfish also prefer to settle in shallow water, often on reef flats or in tide pools. Randall (1961) reported that Acanthurus triostegus sandvicensis in Hawaii, USA, settle primarily to tidepools where settlers transform into juveniles. Sale (1969b) found that there was a significant positive relationship between the size of juvenile $A$. triostegus sandvicensis and the depth of the tidepool at which they were sighted. It may be that ocean surgeonfish in St. Croix are settling to tidepools on other parts of the island; however, in Tague Bay there is only a bank-barrier reef behind which is a gradually sloping lagoon up to a sandy shore.

It is interesting that there were so few settlers and recruits in the seagrass zones, as these areas are widely held to be an important nursery habitat for young fishes (e.g. Bell \& Pollard 1989). The juveniles of many species, some of which are obligate reef dwellers as adults, are commonly found there (Ogden \& Zieman 1977. Wienstein \& Heck 1979, Baelde 1990). Seagrasses are thought to be especially important in the Caribbean, where grassy areas are more extensive than coral reefs and therefore may offer a larger settlement target (Parrish 1989). Additionally, seagrass provides shelter from predators (Shulman 1985b).

If settlement choice is an adaptive trait, then one would expect to find greater fitness in preferred habitats. Such a pattern was seen in the persistence of ocean surgeonfish, although the attenuation in differences among zones suggests that other factors play a role in determining fitness. Settlement to the back-reef was 20 times greater than settlement to the fore-reef, and 14 times greater than settlement to the back-reef seagrass. The numbers of recruits collected were 2 and 5 times as great, respectively. Because all individuals within the quadrats were removed by means of collections, recruits could come from only 2 sources: the survival of settlers arriving between collections, and immigration from surrounding areas. The fact that the ratio of settlers collected on the back-reef compared to the other zones was greater than the ratio of recruits collected in the back-reef zone compared to the other zones suggests that either immigration rates are lower on the back-reef or emigration rates and predation are higher. It would be interesting to know whether density-dependent predation was occurring and thus decreasing the number of settlers on the back-reef to a greater extent than that in the other zones.

The among-zone pattern of ocean surgeonfish settlement that I observed is most likely the result of active selection by larvae for particular sites. Because Tague Bay is enclosed by the reef, larvae must first pass over the fore-reef before reaching the back-reef. If settlement were a passive. filtering process, then one would expect to find more settlers on the fore-reef and a decrease in settlement intensity as one moved inshore. However, settlement was lower on the fore-reef than it was on the back-reef. The impetus for choosing to settle on the back-reef, if this behaviour is an adaptive trait, must be some aspect of fitness. A separate growth rate study that I conducted, however, suggested that there are no differences in early growth rates among zones (Risk 1996). Investigations of other measures of fitness, such as later post-settlement growth, rates of survival or access to mates, may provide clues as to why ocean surgeonfish prefer to settle to back-reef areas.

Regardless of the existence of an adaptive reason for higher settlement to the back-reef zone, decisions made by ocean surgeonfish as to where to settle can result in settlement patterns being quite different from those predicted by larvae being passively filtered as they move over reefs. This is suggested by the pattern of ocean surgeonfish settlement that I found in Tague Bay, as well as the pattern of ocean surgeonfish recruitment which Sponaugle \& Cowen (1996) found off the coast of Barbados. While more competent ocean surgeonfish larvae were caught at sites in northern Barbados, recruitment was highest to southern sites. Additionally, habitat characteristics that were strongly correlated with high densities of ocean surgeonfish recruits were more common at the southern sites.

\section{Within-zone patterns of settlement and persistence}

The strongest evidence for habitat choice at settlement is at the within-zone scale, in which there is a 
variety of different substrata (Williams 1991). While there may be a lack of pattern to recruitment at a larger scale, this lack of pattern often disappears when the study is scaled down. Victor (1986b), for example, monitored recruitment of Thalassoma bifasciatum at several spatial scales in Panama. He found that at a large scale (among 24 reefs) there was considerable variation in recruitment intensity, while at a small scale (within one patch reef) $T$. bifasciatum showed distinct preferences for flat dead coral surfaces. Similarly, when Tolimieri (1995) examined recruitment of Stegastes planifrons among 9 sites on 3 islands in the Caribbean, he found high recruitment variation among sites that was uncorrelated with habitat characteristics. Yet, within a site he found a strong correlation between $S$. planifrons recruitment and the abundance of the coral Montastrea annularis. Most workers have found that the preferred habitats of reef fishes can be readily defined in terms of substratum type or physical relief (Doherty 1983, Jones 1984a, b, Sale et al. 1984b, Carr 1989, 1991, Levin 1993).

Substratum characteristics clearly influenced the settlement of ocean surgeonfish on the Tague Bay backreef, with more settlers occupying pavement than would be expected by chance. Persistence was also greater on pavement. This increased persistence may be due to either lower predation risk, lower emigration rates, or a combination of the two. Although pavement is much less structurally complex than some other substrata (e.g. coral), it still has within it holes and crevices that are used as shelter by individuals (pers. obs.). Shulman (1985a) found that ocean surgeonfish recruits aggressively defended shelter holes in reefs that had been constructed of conch shells. Individuals slept in the same hole for several days. Movement to a new shelter hole was made gradually, with defence of both the new and the old holes occurring during the transition period. These results therefore suggest that the availability of suitable shelter can be an important factor determining the distribution of juvenile ocean surgeonfish

Additionally, persistence may be higher on pavement because high quality food resources reduce emigration rates. The algae Laurencia sp., Gelidia sp. and Acanthophora sp., as well as epiphytic algae, are found on the back-reef and are common food items of surgeonfish (Ogden \& Lobel 1978, Carpenter 1990). Following the die-off of the sea urchin Diadema antillarum, a ubiquitous Caribbean herbivore, Carpenter (1988) found that grazing intensity by surgeonfish and parrotfish on the back-reef of Tague Bay immediately increased almost 4 -fold. Similarly, Hay \& Taylor (1985) removed $D$. antillarum from a strip of reef in St. Thomas, U.S. Virgin Islands, and found that the densities of surgeonfish and parrotfish increased signifi- cantly within several weeks when compared to adjacent control sites. These findings suggest that competition for food may be occurring, and that settlement to algae-covered areas may confer a fitness advantage. Taken together, the results of this study suggest that patterns of ocean surgeonfish settlement among zones and among substrata within zones are not simply a function of larval supply. The initial distribution of ocean surgeonfish settlers among reef zones is most likely the result of settlement choice, although subsequent post-settlement modification may occur. The initial distribution of settlers among substrata on the back-reef is also most likely the result of choices made at settlement, and is subsequently reinforced by higher persistence on preferred substrata.

Acknowledgements. This paper was improved by comments from P. F. Sale and B. Danilowicz, as well as 2 anonymous reviewers. Helpful discussions were provided by $\mathrm{N}$. Tolimieri and S. Roe, while D. Ha assisted with field work. Research was funded by a graduate scholarship from the Natural Sciences and Engineering Research Council of Canada and by grants to P. F. Sale from both the Natural Sciences and Engineering Research Council of Canada (OGP0154284) and the U.S. National Science Foundation (OCE-9018724)

\section{LITERATURE CITED}

Aldenhoven JM (1986) Local variation in mortality rates and life-expectancy estimates of the coral-reef fish Centropyge bicolor (Pisces: Pomacanthidae). Mar Biol 92: 237-244

Baelde P (1990) Differences in the structures of fish assemblages in Thalassia testudinum beds in Guadeloupe, French West Indies, and their ecological significance. Mar Biol 105:163-173

Bell JD, Galzin R (1984) Influence of tive coral cover on coralreef fish communities. Mar Ecol Prog Ser 15:265-274

Bell JD, Pollard DA (1989) Ecology of fish assemblages and fisheries associated with seagrasses. In: Larkum AWD McComb AJ, Shepherd SA (eds) Biology of seagrasses a treatise on the biology of seagrasses with special reference to the Australian region. Elsevier, Amsterdam, p 565-609

Booth DJ (1992) Larval settlement patterns and preferences by domino damselfish Dascyllus albisella Gill. J Exp Mar Biol Ecol 155:85-104

Booth DJ, Beretta GA (1994) Seasonal recruitment, habitat associations and survival of pomacentrid reef fish in the US Virgin Islands. Coral Reefs 13:81-89

Butman CA (1987) Larval settlement of soft sediment invertebrates: the spatial scales of pattern explained by active habitat selection and the emerging role of hydrodynamical processes. Oceanogr Mar Biol Annu Rev 25:113-165

Caffey HM (1985) Spatial and temporal variation in settlement and recruitment of intertidal barnacles. Ecol Monogr 55:313-332

Carpenter RC (1988) Mass mortality of a Caribbean sea urchin: immediate effects on community metabolism and other herbivores. Proc Natl Acad Sci USA. 85:511-514

Carpenter RC (1990) Mass mortality of Diadema antillarum. II. Effects on population densities and grazing intensity of parrotfishes and surgeonfishes. Mar Biol 104:79-86 
Carr MH (1989) Effects of macroalgal assemblages on the recruitment of temperate zone reef fishes. J Exp Mar Biol Ecol 126:59-76

Carr MH (1991) Habitat selection and recruitment of a assemblage of temperate zone reef fishes. J Exp Mar Biol Ecol 146:113-137

Choat JH, Bellwood DR (1985) Interactions amongst herbivorous fishes on a coral reef: influence of spatial variation. Mar Biol 89:221-234

Colin PL, Clavijo IE (1988) Spawning activity of fishes producing pelagic eggs on a shelf edge coral reef, southwestern Puerto Rico. Bull Mar Sci 43:249-279

Doherty PJ (1981) Coral reef fishes: recruitment-limited assemblages? Proc 4th Int Coral Reef Symp 2:465- 470

Doherty PJ (1983) Tropical territorial damselfishes: is density limited by aggression or recruitment? Ecology 64:176-190

Doherty PJ (1987) The replenishment of populations of coral reef fishes, recruitment surveys, and the problems of variability manifest on multiple scales. Bull Mar Sci 41: $411-422$

Doherty PJ, Fowler AT (1994a) An empirical test of recruitment limitation in a coral reef fish. Science 263:935-939

Doherty PJ, Fowler AT (1994b) Demographic consequences of variable recruitment to coral reef fish populations: a congeneric comparison of two damselfishes. Bull Mar Sci 54: 297-313

Doherty P.J. Williams DMrB (1988) The replenishment of cora! reef fish populations. Oceanogr Mar Biol Annu Rev 26 $487-551$

Doherty PJ, Williams DMcB, Sale PF (1985) The adaptive significance of larval dispersal in coral reef fishes. Environ Biol Fishes 12:81-90

Ebersole JP (1985) Niche separation of two damselfish species by aggression and differential microhabitat utilization. Ecology 66:14-20

Eckert GJ (1985) Settlement of coral reef fishes to different natural substrata and at different depths. Proc 5th Int Coral Reef Congr 5:385-390

Eckert GJ (1987) Estimates of adult and juvenile mortality for labrid fishes at One Tree Reef, Great Barrier Reef. Mar Biol 95:167-171

Ehrlich PR (1975) The population biology of coral reef fishes Annu Rev Ecol Syst 6:211-247

Forrester GE (1990) Factors influencing the demography of a coral reef fish. Ecology 71:1666-1681

Fowler AT (1989) Description, interpretation and use of the microstructure of otoliths from juvenile butterflyfishes (family Chaetodontidae). Mar Biol 102:167-181

Fowler AT (1990) Spatial and temporal patterns of distribution and abundance of chaetodontid fishes at One Tree Reef southern GBR. Mar Ecol Prog Ser 64:39-53

Fowler AT, Doherty PJ, Williams DMcB (1992) Multiscale analysis of recruitment of a coral reef fish on the GBR. Mar Ecol Prog Ser 82:131-141

Hay ME, Taylor PE (1985) Competition between herbivorous fishes and urchins on Caribbean reets. Oecologia 65 $591-598$

Hixon MA, Beets JP (1989) Shelter characteristics and Caribbean fish assemblages: experiments with artificial reefs. Bull Mar Sci 444:666-680

Hixon MA, Beets JP (1993) Predation, prey refuges, and the structure of coral-reef fish assemblages. Ecol Monogr 63: 77-101

Itzkowitz M (1977) Spatial organization of the Jamaican damselfish community. J Exp Mar Biol Ecol 28:217-241

Jones GP (1984a) The influence of habitat and behavioural interactions on the local distribution of the wrasse.
Pseudolabrus celidotus. Environ Bio] Fishes 10:43-85

Jones GP (1984b) Population ecology of the temperate reef fish Pseudolabrus celidotus Bloch \& Schneider (Pisces Labridae). I. Factors influencing recruitment. J Exp Mar Biol Ecol 75:257-276

Jones GP (1986) Food availability affects growth in a coral reef fish. Oecologia 70:136-139

Jones GP (1987) Some interactions between residents and recruits in two coral reef fishes. J Exp Mar Biol Ecol 114 $169-182$

Jones GP (1990) The importance of recruitment to the dynamics of a coral reef fish population. Ecology 71:1691-1698

Jones GP (1991) Postrecruitment processes in the ecology of coral reef fish populations: a multifactorial perspective. In: Sale PF (ed) The ecology of fishes on coral reefs. Academic Press, San Diego, p 294-330

Leis JM (1991) The pelagic stage of reef fishes: the larval biology of coral reef fishes. In: Sale PF (ed) The ecology of fishes on coral reefs. Academic Press, San Diego. p $183-230$

Levin PS (1993) Habitat structure, conspecific presence and spatial variation in recruitment of a temperate reef fish. Oecologia 94:176-185

Levin PS (1994) Small-scale recruitment variation in a temperate fish: the roles of macrophytes and food supply. Environ Biol Fishes 40:271-281

Mahon R, Mahon SD (1001) Structure and resilience of a tidepool assemblage at Barbados. Environ Biol Fishes 41: $171-190$

Mapstone BD, Fowler AJ (1988) Recruitment and the structure of assemblages of fish on coral reefs. Trends Ecol Evol 3:72-77

Milicich MJ, Meekan MG, Doherty PJ (1992) Larval supply: a good predictor of recruitment of three species of reef fish (Pomacentridae). Mar Ecol Prog Ser 2:153-166

Ogden JC (1976) Some aspects of herbivore-plant relationships on Caribbean reefs and seagrass beds. Aquat Bot 2: $103-116$

Ogden JC, Lobel PS (1978) The role of herbivorous fishes and urchins in coral reef communities. Environ Biol Fishes 3: $49-63$

Ogden JC, Zieman JC (1977) Ecological aspects of coral-seagrass bed contacts in the Caribbean. Proc 3rd Int Coral Reef Symp 1:377-382

Parrish JD (1989) Fish communities of interacting shallowwater habitats in tropical oceanic regions. Mar Ecol Prog Ser 58:143-160

Raimondi PT (1990) Patterns, mechanisms, consequences of variability in settlement and recruitment of an intertidal barnacle. Ecol Monogr 60:283-309

Randall JE (1961) A contribution to the biology of the convict surgeonfish of the Hawaii Islands, Acanthurus triostegus sandvicensis. Pac Sci 15:215-272

Randall JE (1965) Grazing effects on seagrasses by herbivorous reef fishes in the West Indies. Ecology 46:255-260

Risk A (1996) Factors affecting the early life history of the ocean surgeonfish. Acanthurus bahianus. Master's thesis, University of Windsor

Robertson DR (1988) Abundances of surgeonfishes on patchreefs in Caribbean Panamá: due to settlement, or postsettlement events? Mar Biol 97:495-501

Robertson DR (1992) Patterns of lunar settlement and early recruitment in Caribbean reef fishes at Panamá. Mar Biol $114: 527-537$

Roughgarden J, Gaines S, Possingham H (1988) Recruitment dynamics in complex life cycles. Science 241:1460-1466

Sale PF (1968) Influence of cover availability on depth prefer- 
ence of the juvenile Manini, Acanthurus triostegus sandvicensis. Copeia 1968:802-807

Sale PF (1969a) A suggested mechanism for habitat selection by the juvenile Manini Acanthurus triostegus sandvicen. sis Streets. Behaviour 35:27-44

Sale PF (1969b) Pertinent stimuli for habitat selection by the juvenile Manini Acanthurus triostegus sandvicensis Ecology 50:616-623

Sale PF (1980) The ecology of fishes on coral reefs. Oceanogr Mar Biol Annu Rev 18:367-421.

Sale PF, Doherty PJ, Eckert GJ, Douglas WA, Ferrell DJ (1984a) Large-scale spatial and temporal variation in recruitment to fish populations on coral reefs. Oecologia $64: 191-198$

Sale PF, Douglas WA, Doherty PJ (1984b) Choice of microhabitats by coral reef fishes at settlement. Coral Reefs 3 91-99

Schmitt RJ, Holbrook SJ (1986) Seasonally fluctuating resources and temporal variability of interspecific competition. Oecologia 69:1-11

Shulman MJ (1984) Resource limitation and recruitment patterns in a coral reef fish assemblage. J Exp Mar Biol Ecol $74: 85-109$

Shulman MJ (1985a) Coral reef fish assemblages: intra- and interspecific competition for shelter sites. Environ Biol Fishes 13:81-92

Shulman MJ (1985b) Recruitment of coral reef fishes: effects of distribution of predators and shelter. Ecology 66: $1056-1066$

Sponaugle S, Cowen RK (1996) Larval supply and patterns of recruitment for two Caribbean reef fishes, Stegastes partitus and Acanthurus bahianus. Mar Freshwat Res 47

Sweatman HPA (1985) The influence of adults of some coral

Editorial responsibility: Charles Peterson (Contributing

Editor), Morehead City, North Carolina, USA reef fishes on larval recruitment. Ecol Monogr 55:469-485 Sweatman HPA (1988) Field evidence that settling coral reef fish larvae detect resident fishes using dissolved chemical cues. J Exp Mar Biol Ecol 124:163-174

Thresher RE, Colin PL, Bell LJ (1989) Planktonic duration, distribution and population structure of western and central Pacific damselfıshes (Pomacentridae). Copeia 1989: $420-434$

Tolimieri N (1995) Effects of microhabitat characteristics on the settlement and recruitment of a coral reef fish at two spatial scales. Oecologia 102:52-63

Victor BC (1983) Recruitment and population dynamics of a coral reef fish. Science 219:419-420

Victor BC (1986a) Duration of the planktonic larval stage of one hundred species of Pacific and Atlantic wrasses (family Labridae). Mar Biol 90:317-326

Victor BC (1986b) Larval settlement and juvenile mortality in a recruitment-limited coral reef fish population. Ecol Monogr 56:145-160

Victor BC (1986c) Delayed metamorphosis with reduced larval growth in a coral reef fish (Thalassoma bifasciatum). Can J Fish Aquat Sci 43:1208-1213

Weinstein MP, Heck KL (1979) Ichthyofauna of seagrass meadows along the Caribbean coast of Panama and in the Gulf of Mexico: composition, structure and community ecology. Mar Biol 50:97-107

Wellington GM, Victor BC (1989) Planktonic larval duration of one hundred species of Pacific and Atlantic damselfishes (Pomacentridae). Mar Biol 101:557-567

Williams DMcB (1991) Patterns and processes in the distribution of coral reef fishes. In: Sale PF (ed) The ecology of fishes on coral reefs. Academic Press, San Diego, p $437-474$

Submitted: August 23, 1996; Accepted: October 22, 1997 Proofs received from author(s): December 24, 1997 